\title{
Fertilization Improves Cold Tolerance in Coconut Palm
}

\author{
Timothy K. Broschat ${ }^{1}$
}

AdDitional INDEX wORDs. nitrogen, potassium, Cocos nucifera, chilling injury

Summary. Coconut palms (Cocos nucifera) in a field planting that were fertilized with a $8 \mathrm{~N}-0.9 \mathrm{P}-10 \mathrm{~K}-4 \mathrm{Mg}$ fertilizer four times per year or were never fertilized experienced chilling injury (CI) temperatures in 2008, 2009, and 2010. Fertilized coconut palms had significantly less foliar necrosis in each year than unfertilized palms and also retained more of their fruits. The number of leaves supported by each palm, a measure of potassium (K) deficiency severity, was improved by fertilization and was negatively correlated with percentage of necrosis of the foliage caused by cold temperatures. Nitrogen and $K$ concentrations in leaf 1 of coconut palms were also negatively correlated with CI severity.

$\mathrm{T}$ The relationship between fertilization and cold tolerance of plants is a confusing one. Plant nutrition involves a number of different elements, each of which may affect a plant's cold tolerance in a different manner. Most studies on fertility effects on cold tolerance have concentrated on nitrogen $(\mathrm{N})$, which can have positive (DeHayes et al., 1989; Proebesting, 1961; Smith and Cotton, 1985), negative (Kelley, 1972), or no (Pellett, 1969, 1973; Smiley and Shirazi, 2003) influence on cold tolerance. Similarly, potassium has been shown to have positive (Webster and Ebdon, 2005), negative (Beattie and Flint, 1973), or no (Cook and Duff, 1976; Kelley, 1972) influence on the cold tolerance of plants. Potassium is thought to have positive effects on plants subjected to diseases and other physiological stresses, but there are relatively few published papers documenting these effects of this element in palms (Turner, 1981; von Uexkull, $1982,1991)$ and none relating to cold damage in palms.

Cold injury is a recurring problem in palms grown in climates cooler than those to which they are adapted. Strictly tropical species such as coconut palm often exhibit symptoms of foliar or even trunk injury in response to temperatures below $40{ }^{\circ} \mathrm{F}$,

University of Florida, Fort Lauderdale Research and Education Center, 3205 College Avenue, Davie, FL 33314

This research was supported by the Florida Agricultural Experiment Station.

I wish to thank William Latham and Susan Thor for their assistance in this study.

${ }^{1}$ Corresponding author. E-mail: tkbr@ufl.edu. especially if the plants have not been acclimated to cool temperatures.

Potassium deficiency is the most common nutrient deficiency in palms grown within the United States, especially in the in the gulf and Atlantic coastal plain soils of the southeastern United States. Potassium deficiency can cause premature leaf senescence and limits the number of leaves that a palm will retain within its canopy (Broschat, 2010). Visible symptoms vary among species, but typically include translucent yellow-orange and/ or necrotic spotting on the oldest leaves. As the deficiency becomes more severe, leaflet tip necrosis becomes the predominant symptom (Broschat, $1990,2010)$. Because $\mathrm{K}$ is a mobile element within palms, symptoms are most severe on the oldest leaves and toward the tips of those leaves. This symptom distribution pattern helps to differentiate between $\mathrm{K}$ deficiency and chilling injury (CI) symptoms because CI causes leaflet necrosis uniformly throughout the entire length of the leaf blade. CI may also affect mid- to lower canopy leaves equally, and, in more severe cases, affects all but the youngest leaf or two in the canopy. Freezing temperatures will damage the leaflets on these leaves as well, and, in severe freezes, petiole, rachis, and spear leaf (the newly emerging unexpanded leaf), and ultimately, meristematic tissue will also become necrotic in palms. The purpose of this study was to determine the relationship between fertility and cold tolerance in coconut palm.

\section{Materials and methods}

A plot of malayan dwarf coconut palms about 6 to $10 \mathrm{~m}$ in overall height planted in the mid-1980s was used to study the effects of fertilization on canopy size beginning in July 2006. Before that time, no fertilizers had ever been applied to any of the trees. This plot was located in Davie, FL (lat. $26^{\circ} 5^{\prime} 1.11^{\prime \prime} \mathrm{N}$, long. $80^{\circ} 14^{\prime} 36.44^{\prime \prime} \mathrm{W}$ ). The soil was a Margate fine sand soil with an average $\mathrm{pH}$ of 6.1 and a cation exchange capacity of $7.5 \mathrm{meq} / 100 \mathrm{~g}$. The palms were spaced $20 \mathrm{ft}$ apart in rows $20 \mathrm{ft}$ apart. Due to the extensive spread and overlap of the root systems of these palms, a split plot design was used, with a 100 -ft-wide buffer area between fertilized and unfertilized subplots. Twenty replicate palms were fertilized every 3 months by broadcasting a $8 \mathrm{~N}-0.9 \mathrm{P}-10 \mathrm{~K}-4 \mathrm{Mg}$ plus micronutrients fertilizer (Howard Fertilizer Co., Groveland, FL) at a rate of $15 \mathrm{lb} / 1000 \mathrm{ft}^{2}$ in 8 -ft-wide bands along each side of the palm rows using a rotary spreader (C25HDS; Earthway Products, Bristol, IN). A similar block of control palms was never fertilized. None of the palms received any supplemental irrigation, but rainfall in the area averages about 60 inches per year.

The number of living leaves was counted for each palm once per year in November as a measure of $\mathrm{K}$ deficiency severity. Although increasing the amount of $\mathrm{K}$ in a palm will increase the number of leaves in the canopy, it will not eliminate visible $\mathrm{K}$ deficiency symptoms on the oldest leaves until the canopy size has reached its full genetic potential for each species. For this reason, the number of leaves in the canopy of a palm is a better indicator of palm $\mathrm{K}$ status than the severity of the visible symptoms on the oldest leaves. Other mobile elements such as

\begin{tabular}{|c|c|c|c|}
\hline \multicolumn{4}{|l|}{ Units } \\
\hline $\begin{array}{l}\text { To convert U.S. to SI, } \\
\text { multiply by }\end{array}$ & U.S. unit & SI unit & $\begin{array}{l}\text { To convert SI to U.S., } \\
\text { multiply by }\end{array}$ \\
\hline $\begin{array}{l}0.3048 \\
4.8824 \\
1 \\
\left({ }^{\circ} \mathrm{F}-32\right) \div 1.8\end{array}$ & $\begin{array}{l}\mathrm{ft} \\
\mathrm{lb} / 1000 \mathrm{ft}^{2} \\
\mathrm{meq} / 100 \mathrm{~g} \\
{ }^{\circ} \mathrm{F}\end{array}$ & $\begin{array}{l}\mathrm{m} \\
\mathrm{g} \cdot \mathrm{m}^{-2} \\
\mathrm{cmol} \cdot \mathrm{kg}^{-1} \\
{ }^{\circ} \mathrm{C}\end{array}$ & $\begin{array}{l}3.2808 \\
0.2048 \\
1 \\
\left(1.8 \times{ }^{\circ} \mathrm{C}\right)+32\end{array}$ \\
\hline
\end{tabular}


$\mathrm{N}$, phosphorus $(\mathrm{P})$, and magnesium $(\mathrm{Mg})$ could also potentially reduce the canopy size in palms, but because deficiency symptoms of these elements were never observed in the experimental palms, it is unlikely that they had any significant effect on canopy size. Similarly, because micronutrient deficiencies affect only newly developing leaves (Elliott et al., 2004; Broschat, 2010), these deficiencies are not known to affect palm canopy leaf number.

On 3 Jan. 2008, temperatures below $40{ }^{\circ} \mathrm{F}$ for $6 \mathrm{~h}\left[\right.$ minimum $=37^{\circ} \mathrm{F}$ (Fig. 1)] caused CI on coconut palms. On 29 Jan. 2008, the percentage of the leaf surface area of each palm that was necrotic was estimated. On 5 Feb. 2009 , temperatures that dropped below $40{ }^{\circ} \mathrm{F}$ for nearly $5 \mathrm{~h}$ (minimum = $36^{\circ} \mathrm{F}$ ) also caused $\mathrm{CI}$, and on $12 \mathrm{Feb}$. 2009 all palms were similarly evaluated. Prolonged cold temperatures were experienced during the winter of 2009-10 with $31 \mathrm{~h}$ of temperatures below $40{ }^{\circ} \mathrm{F}$ between 6 and 11 Jan. 10 (minimum $=$ 36,33 , and $34^{\circ} \mathrm{F}$ on 6,10 , and 11 Jan., respectively). Temperature data were obtained from the Florida Automated Weather Network (University of Florida, 2010), which has a monitoring station about $300 \mathrm{~m}$ from the experimental plot. The percentage of necrosis of the leaf tissue due to cold

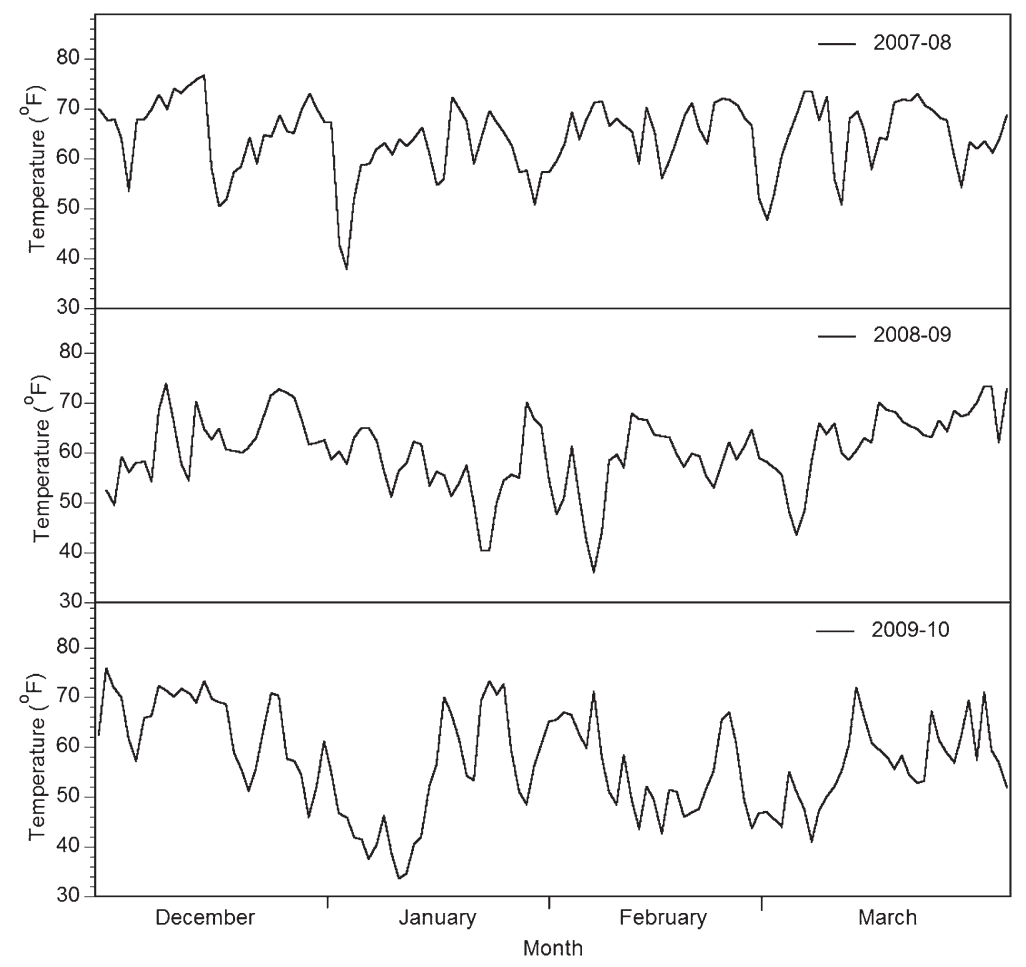

Fig. 1. Minimum daily temperatures measured at $2 \mathrm{~m}(6.6 \mathrm{ft})$ height by the University of Florida's automated weather station (University of Florida, 2010) for the experimental site in Davie, FL, during winters of $2008-10 ;\left({ }^{\circ} \mathrm{F}-32\right) \div 1.8={ }^{\circ} \mathrm{C}$.

temperatures was estimated on 12 Feb. 2010, and on 18 May 2010, the total number of green, necrosis-free leaves was counted for each palm. Because fruit drop in coconut palm appeared to be related to CI, the number of fruits remaining on each tree was counted in 2009 and 2010.

Samples consisting of four of the central leaflets on the youngest fully expanded leaf (leaf 1 ) of each palm were collected on 17 Feb. 2009 and 13 Feb. 2010 for leaf nutrient analysis. Leaves were dried at $60^{\circ} \mathrm{C}$, ground, digested using a sulfuric acid-peroxide method (Wolf, 1982), and analyzed for $\mathrm{N}$ using an ammonia electrode (Greenberg et al., 1992) and for K using atomic absorption spectroscopy (Wright and Stuczynski, 1996). Data were analyzed by analysis of variance and regression analysis using SAS (version 9.1; SAS Institute, Cary, NC).

\section{Results and discussion}

The number of leaves retained in the canopies of fertilized coconut palms slowly increased from an average of 17.5 leaves in 2006 when fertilization began to 24.6 leaves in late 2009 (Table 1). Canopy size in unfertilized coconut palms remained at about 17 leaves throughout the study period.

An average of $32.5 \%$ of the foliage of unfertilized coconut palms became necrotic following chilling temperatures in Jan. 2008 compared with $5.8 \%$ for fertilized palms (Table 1 ). In $2009,30.6 \%$ of the foliage of unfertilized coconut palms was necrotic due to chilling temperatures, while fertilized palms sustained virtually no damage. In $2010,67.3 \%$ of the foliage became necrotic due to chilling temperatures for unfertilized palms compared with $32.5 \%$ for the fertilized palms (Table 1).

Table 1. Effects of fertilization with a $8 \mathrm{~N}-0.9 \mathrm{P}-10 \mathrm{~K}-4 \mathrm{Mg}$ fertilizer on potassium (K) deficiency severity (quantified by the number of leaves retained) and CI severity (indicated by the percentage of necrosis of the canopy foliage), number of fruit retained, and number of green, symptom-free leaves remaining on coconut palms after chilling events during $2008-10$ $(\mathrm{n}=20$ palms per treatment $)$.

\begin{tabular}{|c|c|c|c|c|c|c|c|c|c|}
\hline \multirow[b]{2}{*}{ Fertilizer } & \multicolumn{2}{|c|}{2008} & \multicolumn{3}{|c|}{2009} & \multicolumn{4}{|c|}{2010} \\
\hline & $\begin{array}{c}\text { Leaves } \\
\text { (no.) }\end{array}$ & $\begin{array}{c}\text { Necrosis }^{z} \\
(\%)\end{array}$ & $\begin{array}{c}\text { Leaves } \\
\text { (no.) }\end{array}$ & $\begin{array}{c}\text { Necrosis } \\
(\%)^{\mathrm{y}}\end{array}$ & $\begin{array}{l}\text { Fruit } \\
(\text { no. })^{y}\end{array}$ & $\begin{array}{c}\begin{array}{c}\text { Leaves } \\
\text { (no.) }\end{array} \\
\end{array}$ & $\begin{array}{c}\text { Necrosis } \\
(\%)^{x}\end{array}$ & $\begin{array}{l}\text { Fruit } \\
{\text { (no. })^{x}}^{-}\end{array}$ & $\begin{array}{c}\text { Green leaves } \\
\text { (no.) })^{\mathrm{w}}\end{array}$ \\
\hline No & 17.7 & 32.5 & 17.1 & 30.6 & 1.6 & 17.3 & 67.3 & 3.7 & 1 \\
\hline$P$ value ${ }^{\mathrm{v}}$ & 0.0047 & 0.0001 & 0.0001 & 0.0001 & 0.0001 & 0.0001 & 0.0001 & 0.0001 & 0.021 \\
\hline
\end{tabular}

${ }^{2} 26 \mathrm{~d}$ post-cold weather.

${ }^{7} 7 \mathrm{~d}$ post-cold weather.

$\times 31$ d post-cold weather.

w126 d post-cold weather.

vrobability values from the analysis of variance. 
We observed in 2009 that virtually all immature fruit dropped off unfertilized coconut palms within a day or two following a chilling event compared with only $1 \%$ to $2 \%$ of the immature fruit of fertilized palms. While fertilized coconut palms produced many more fruit than unfertilized palms (T.K. Broschat, personal observation), immature fruit drop was disproportionately greater for unfertilized palms. In 2010, because of the prolonged cold weather, fewer fruit were retained by fertilized palms than in the previous year (Table 1$)$. Larcher and Winter (1981) demonstrated that flowers and fruit were damaged at much higher temperatures than vegetative tissue in windmill palm (Trachycarpus fortunei).

Fertilized coconut palms had significantly greater $\mathrm{N}$ and $\mathrm{K}$ concentrations in their foliage than unfertilized palms in 2009 and 2010 (Table 2).

Table 2. Effects of fertilization with a $8 \mathrm{~N}-0.9 \mathrm{P}-10 \mathrm{~K}-4 \mathrm{Mg}$ fertilizer on leaf 1 (youngest fully expanded leaf) nitrogen $(\mathrm{N})$ and potassium $(\mathrm{K})$ concentrations of coconut palms in 2009 and 2010 ( $n=20$ palms per treatment).

\begin{tabular}{lccccc}
\hline & \multicolumn{2}{c}{2009} & & \multicolumn{2}{c}{2010} \\
\cline { 2 - 3 } \cline { 5 - 6 } Fertilizer & Leaf N (\%) & Leaf K (\%) & & Leaf N (\%) & Leaf K (\%) \\
\hline Yes & 1.65 & 1.3 & & 1.75 & 1.21 \\
No & 1.25 & 0.5 & & 1.16 & 0.67 \\
v value $^{\mathrm{z}}$ & 0.0009 & 0.0001 & & 0.0001 & 0.0001 \\
\hline
\end{tabular}

${ }^{2}$ Probability values from the analysis of variance.
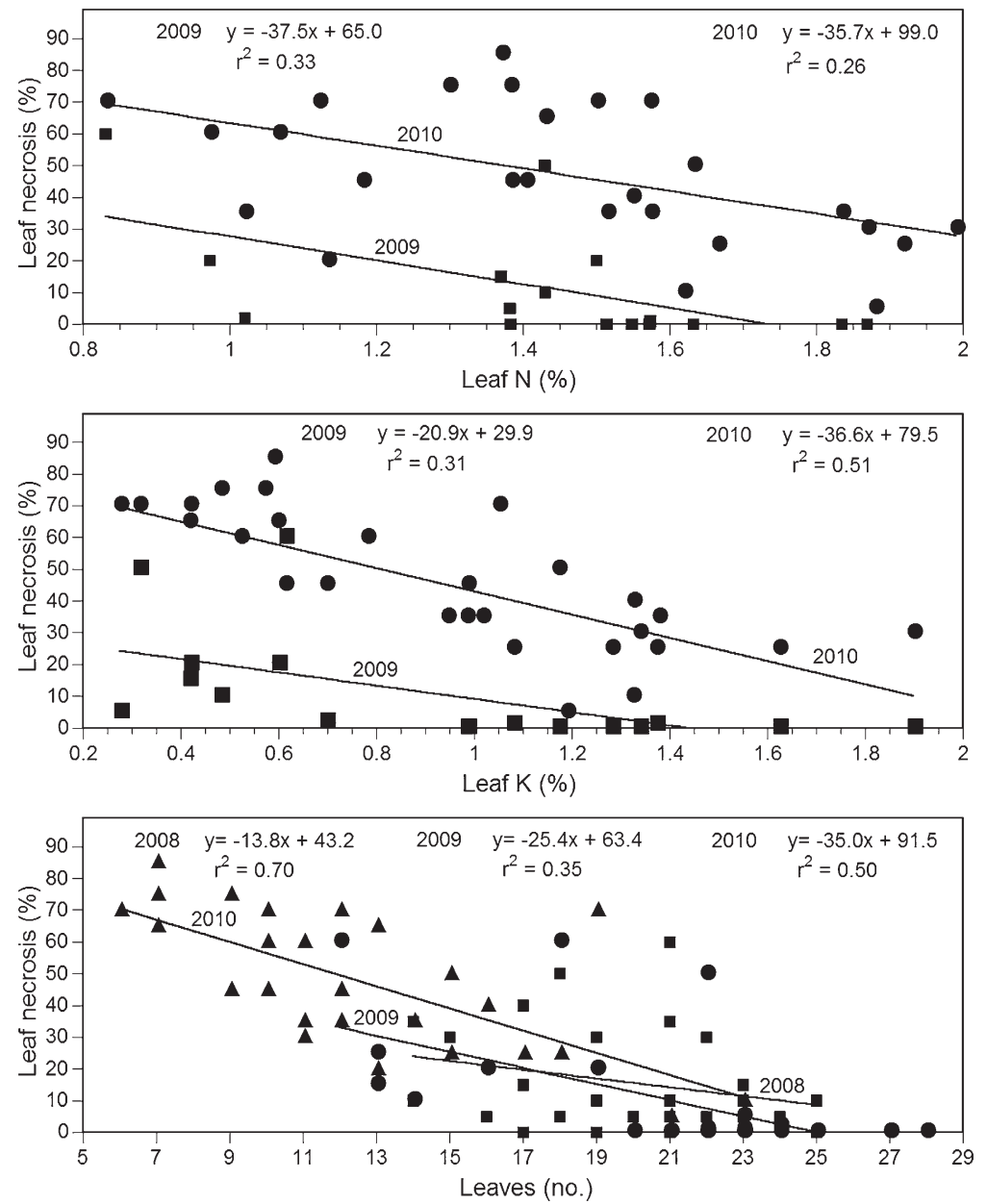

Fig. 2. Regression analysis of coconut palm leaf 1 (youngest fully expanded leaf) nitrogen $(\mathrm{N})$ and potassium $(\mathrm{K})$ concentrations and number of leaves versus the percentage of necrosis of the leaves caused by cold temperatures in 2008, 2009, and 2010. All regressions are significant at $P<0.01(\mathrm{n}=20)$.
Regression analysis showed that CI severity was reduced as foliar $\mathrm{N}$ and $\mathrm{K}$ concentrations increased or number of leaves (a measure of K deficiency severity) increased (Fig. 2). The $\mathrm{N} \times \mathrm{K}$ interactive term in these analyses was non-significant in all cases (data not shown). Because $\mathrm{N}$ and $\mathrm{K}$, as well as $\mathrm{P}$, $\mathrm{Mg}$, manganese ( $\mathrm{Mn})$, iron (Fe), zinc $(\mathrm{Zn})$, copper $(\mathrm{Cu})$, and boron $(\mathrm{B})$ were applied to the fertilized coconut palms, it was not possible in this study to determine which of these elements was responsible for the observed response.

In all years, necrosis was most severe in the oldest leaves of the canopy and was least so in the youngest leaves of coconut palm. Larcher and Winter (1981) showed that immature leaves of windmill palm tolerated temperatures up to $4{ }^{\circ} \mathrm{C}$ lower than mature leaves on the same palm. The distribution of CI symptoms within the canopy corresponds to those of $\mathrm{N}$ and $\mathrm{K}$ concentrations within the foliage of coconut palms. Broschat (1997) showed that foliar $\mathrm{N}$ concentrations decreased by $26 \%$ from leaf 1 (youngest fully expanded leaf) to leaf 13 (the oldest leaf on unfertilized coconut palms) while $\mathrm{K}$ concentrations dropped by $64 \%$ within those same leaves. Because K plays a role in osmotic regulation within plant cells (Mengel and Kirkby, 1979), increasing $\mathrm{K}$ concentrations within the foliage of coconut palms may enhance plant cold tolerance.

In conclusion, fertilization significantly improved cold tolerance of $\mathrm{co}^{-}$ conut palms. However, further research will be needed to determine which element(s) was responsible for this increase in cold tolerance.

\section{Literature cited}

Beattie, D.J. and H.L. Flint. 1973. Effect of $\mathrm{K}$ level on frost hardiness of stems of Forsythia $\times$ intermedia Zab. 'Lynwood'. J. Amer. Soc. Hort. Sci. 98:539-541.

Broschat, T.K. 1990. Potassium deficiency of palms in south Florida. Principes 34:151-155.

Broschat, T.K. 1997. Nutrient distribution, dynamics, and sampling in coconut and canary island date palms. J. Amer. Soc. Hort. Sci. 122:884-890.

Broschat, T.K. 2010. Palm nutrition and fertilization. HortTechnology 19:690694.

Cook, T.W. and D.T. Duff. 1976. Effects of $\mathrm{K}$ fertilization on freezing tolerance and 
carbohydrate content of Festuca arundinacea Schreb. maintained as turf. Agron. J. 68:116-119.

DeHayes, D.H., M.A. Ingle, and C.E. Waite. 1989. Nitrogen fertilization enhances cold tolerance of red spruce seedlings. Can. J. For. Res. 19:1037-1043.

Elliott, M.L., T.K. Broschat, J.Y. Uchida, and G.W. Simone (eds.). 2004. Compendium of ornamental palm diseases and disorders. APS Press, St. Paul, MN.

Greenberg, A.E., L.S. Clesceri, and A.D. Eaton. 1992. Standard methods for the examination of water and waste water. 17th ed. Amer. Public Health Assn. Washington, DC.

Kelley, J.D. 1972. Leaf nitrogen and winter hardiness of Pyracantha coccinea 'Lalandi' and Ilex crenata 'Rotundifolia'. J. Amer. Soc. Hort. Sci. 97:446-448.

Larcher, W. and A. Winter. 1981. Frost susceptibility of palms: Experimental data and their interpretation. Principes 25: 143-152.

Mengel, K. and E.A. Kirkby. 1979. Principles of plant nutrition. 2nd ed. International Potash Inst., Berne, Switzerland.
Pellett, N.E. 1969. Effect of soil nitrogen and soil moisture levels on the cold acclimation of container-grown Juniperus chinensis 'Hetzii'. J. Amer. Soc. Hort. Sci. 94: 457-459.

Pellett, N.E. 1973. Influence of nitrogen and phosphorus fertility on cold acclimation of roots and stems of two containergrown woody plant species. J. Amer. Soc. Hort. Sci. 98:82-86.

Proebesting E.L., Jr. 1961. Cold hardiness of Elberta peach fruit buds as influenced by nitrogen level and cover crops. Proc. Amer. Soc. Hort. Sci. 77:97-106.

Smiley, E.T. and A.M. Shirazi. 2003. Fall fertilization and cold hardiness in landscape trees. J. Arboriculture 29:342-346.

Smith, M.W. and B.C. Cotton. 1985. Relationship of leaf elemental concentrations and yield to cold damage of 'Western’ pecan. HortScience 20:420-422.

Turner, P.D. 1981. Oil palm diseases and disorders. Oxford Univ. Press, Oxford, UK.

University of Florida. 2010. Florida Automated Weather Network, report generator.
27 May 2010. <http://fawn.ifas.ufl.edu/ generator/data/reports/>.

Von Uexkull, H.R. 1982. Potassium nutrition and plant diseases. Proc. Intl. Conf. Plant Protection in Tropics, Kuala Lumpur, Malaysia. p. 141-151.

Von Uexkull, H.R. 1991. Fertilizing for high yield and quality in the oil palm. International Potash Inst. Bul. 12.

Webster, D.E. and J.S. Ebdon. 2005. Effects of nitrogen and potassium fertilization on perennial ryegrass cold tolerance during deacclimation in late winter and early spring. HortScience 40:842849 .

Wolf, B. 1982. A comprehensive system of leaf analysis and its use for diagnosis of crop nutrient status. Commun. Soil Sci. Plant Anal. 13:1035-1059.

Wright, R.J. and T.I. Stuczynski. 1996. Atomic absorption and flame emission spectrometry, p. 65-90. In: J.M. Bartels (ed.). Methods of soil analysis. Part. 3. Chemical methods. Soil Sci. Soc. Amer., Madison, WI. 